\title{
SYNTHESIS AND ELECTRICAL CONDUCTIVITY OF TETRA-VALENT CERIUM POLYPHOSPHATE BULKS
}

\author{
Hiroaki Onoda ${ }^{1, *}$, Yousuke Inagaki ${ }^{2}$, Akihide Kuwabara ${ }^{2}$, Naoto Kitamura ${ }^{3}$, Koji Amezawa ${ }^{4}$, \\ Atsushi Nakahira ${ }^{5}$, Isao Tanaka ${ }^{2}$ (*Corresponding author: onoda@kpu.ac.jp) \\ ${ }^{1}$ Department of Informatics and Environmental Sciences, Faculty of Life and Environmental Sciences, Kyoto \\ Prefectural University, 1-5, Shimogamo Nakaragi-cyo, Sakyo-ku, Kyoto 606-8522, Japan \\ ${ }^{2}$ Department of Materials Science and Engineering, Faculty of Engineering, Kyoto University, \\ Yoshida-Honmachi, Sakyo-ku, Kyoto 606-8501, Japan \\ ${ }^{3}$ Department of Pure and Applied Chemistry, Faculty of Science \& Technology, Tokyo University of Science, \\ 2641 Yamazaki, Noda, Chiba 278-8510, Japan \\ ${ }^{4}$ Department of Mechanical and Aerospace Engineering, Faculty of Engineering, Tohoku University, 6-6-01 \\ Aoba, Aramaki, Aoba-ku, Sendai 980-8579, Japan \\ ${ }^{5}$ Department of Materials Science, Biomaterial Group, Faculty of Engineering, Osaka Prefecture University, \\ Gakuencyo 1-1, Sakai 599-8531, Japan
}

Keywords: Sintering, Hot pressing, X-ray methods, Electrical conductivity, Cerium Phosphate

Abstract: Tetra-valent cerium phosphate was synthesized from cerium oxide and phosphoric acid by heating. The sintering processes, pressure-less sintering (PLS), spark plasma sintering (SPS), and hydrothermal hot pressing (HHP), were tried to obtain polyphosphate bulks. Furthermore, the electrical conductivity of cerium polyphosphate bulks was investigated. Tetra-valent cerium phosphate was synthesized by heating at $700^{\circ} \mathrm{C}$ for 20 hours. The hydrothermal hot pressing process was the suitable method to synthesize the tetra-valent cerium phosphate bulk. Y doped $\mathrm{Ce}\left(\mathrm{PO}_{3}\right)_{4}$ had higher conductivity than other rare earth phosphates. A part of tetra-valent cerium cation was considered to reduce tri-valent cerium cation and then to work as a dopant.

\section{INTRODUCTION}

As a new clean energy, a fuel cell technology has been studied in recent decades. Solid oxide fuel cell (SOFC) and polymer electrolyte fuel cell (PEFC) are well known and investigated to work at high and low temperature, respectively. At the middle temperature, phosphate material works as a solid state electrolyte [1-3].

Phosphates are transformed to other forms of phosphates in hydrolysis and dehydration reactions at elevated temperatures [4,5]. Polyphosphate and ultraphosphate are included in a group of condensed phosphates. Polyphosphate has a chain structure in which the $\mathrm{PO}_{4}$ unit shares two oxygen atoms and ultraphosphate has a network structure. These condensed phosphates had a possibility to have novel functional properties. Orthophosphate has been mainly investigated for many use, on the other hand, condensed phosphates have been little studied [6].

Because rare earth phosphates have high melting point, those are suitable materials for solid state electrolyte for use at middle temperature. In rare earth condensed phosphates, there are polyphosphate $\left(\mathrm{R}_{(} \mathrm{PO}_{3}\right)_{3}, \mathrm{R}$; rare earth cation) and ultraphosphate $\left(\mathrm{RP}_{5} \mathrm{O}_{14}\right)$. In previous works, rare earth condensed phosphate had the higher conductivity than orthophosphate, because a small part of condensed phosphate reacted with water in the atmosphere to produce the proton [2,3]. In addition to these condensed phosphates, in cerium phosphates, tetra-valent cerium pyrophosphate $\left(\mathrm{CeP}_{2} \mathrm{O}_{7}\right)$ and polyphosphate $\left(\mathrm{Ce}\left(\mathrm{PO}_{3}\right)_{4}\right)$ were formed because tetra-valent cerium cation is relatively stable. These materials were expected to have unique electrical conductivity, compared with other rare earth phosphates. However, it is difficult to clear the conductivity of target cerium phosphate, because the mixture of some kinds of cerium phosphates was formed.

The electrical conductivity of tri-valent rare earth phosphate was improved by the doping of bi-valent cation, for example $\mathrm{Sr}^{2+}$ [3]. This was considered from that the addition of lower valent cation produced the cation defect. Therefore, tri-valent rare earth cation was doped into tetra-valent cerium polyphosphate to improve the electrical conductivity.

For the measurement of electrical conductivity, the phosphate bulk was required. Tetra-valent cerium polyphosphate transform to cerium oxide losing $\mathrm{P}_{2} \mathrm{O}_{5}$ at high temperature in following equation.

$$
\mathrm{Ce}\left(\mathrm{PO}_{3}\right)_{4} \rightarrow \mathrm{CeO}_{2}+2 \mathrm{P}_{2} \mathrm{O}_{5}
$$


It was difficult to synthesize the phosphate bulk without the decomposition of phosphate structure. Therefore, the sintering process and condition were very important to obtain high density of phosphate bulks [7-11].

In this work, tetra-valent cerium phosphate was synthesized from cerium oxide and phosphoric acid by heating. The sintering processes, pressure-less sintering (PLS), spark plasma sintering (SPS), and hydrothermal hot pressing (HHP), were tried to form polyphosphate bulks. Furthermore, the electrical conductivity of cerium polyphosphate bulks was investigated.

\section{EXPERIMENTAL}

\section{Preparation of cerium polyphosphate}

The mixture of cerium oxide and phosphoric acid in the molar ratio of $\mathrm{P} / \mathrm{Ce}=4$ was kept at $100^{\circ} \mathrm{C}$ for 40 hours. Then the mixture was heated to target temperature in slow heating velocity and holding for 20 hours. Tetra-valent cerium polyphosphate was formed in following equation.

$$
\mathrm{CeO}_{2}+4 \mathrm{H}_{3} \mathrm{PO}_{4} \rightarrow \mathrm{Ce}\left(\mathrm{PO}_{3}\right)_{4}+6 \mathrm{H}_{2} \mathrm{O}
$$

$1 \mathrm{~mol} \%$ of cerium was substituted with yttrium, gadolinium, and ytterbium. These mixtures were treated in the same heating process with the un-doped mixture.

For synthesis of bulks that had high density, the obtained polyphosphates were treated with planetarymill for 30 minutes. The planetary mill was with five balls $\left(15 \mathrm{~mm}\right.$ diameter, $\left.\mathrm{ZrO}_{2}\right)$ and a pot $(40 \mathrm{~mm}$ inside diameter, $40 \mathrm{~mm}$ depth, $\mathrm{ZrO}_{2}$ ). The weight ratio of sample / balls was $10 / 45$.

\section{Synthesis of cerium polyphosphate bulks}

For synthesis of cerium polyphosphate bulks without chemical decomposition, three processes were examined in this work. First, phosphate materials were pressed into a pellet and then heated at several temperatures (up to $825^{\circ} \mathrm{C}$ ) for 20 hours. Spark plasma sintering (SPS) process was also tried to obtain high density of polyphosphate bulks. Phosphates were set in carbon mold, and then heated rapidly to high temperature (up to $950{ }^{\circ} \mathrm{C}$ ) in a decompression chamber. The average heating rate was about $80^{\circ} \mathrm{C} / \mathrm{min}$ and sintering time was 5 minutes in this process. The phosphates were also used as the starting powder for hydrothermal hot pressing (HHP) method [12-14]. The mixture of powder and water or ethanol were set in a mold and mechanically pressed with a uni-axial pressure and subsequently heated at 150 and $200{ }^{\circ} \mathrm{C}$ for 2 hours.

3. Electrical conductivity of tetra-valent cerium polyphosphate bulks

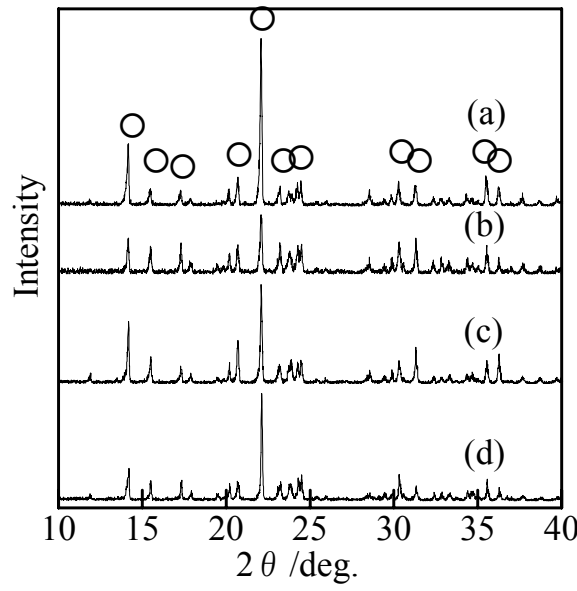

Fig. 1. XRD patterns of samples heated at $700{ }^{\circ} \mathrm{C}$ for 20 hours, $\mathrm{O} ; \mathrm{Ce}\left(\mathrm{PO}_{3}\right)_{4}$, (a) un-doped, (b) $\mathrm{Y}$, (c) $\mathrm{Gd}$, and (d) Yb doped.

Electrical conduction properties of the un-doped and the trivalent rare earth doped $\mathrm{Ce}\left(\mathrm{PO}_{3}\right)_{4}$ were investigated by using conductivity measurement at 400-650 ${ }^{\circ} \mathrm{C}$ under various conditions. Conductivity measurements in $\mathrm{D}_{2} \mathrm{O}$ - containing atmosphere were applied to identify protonic conduction.

\section{RESULTS AND DISCUSSION}

\section{Preparation of cerium polyphosphate}

Cerium oxide is difficult to react with phosphoric acid at room temperature. Because the mixture of cerium oxide and phosphoric acid fiercely reacted to cerium phosphates, samples scattered by heating. Therefore, the mixture was slowly heated to obtain tetra-valent cerium polyphosphate. The suitable condition was to heat at $700{ }^{\circ} \mathrm{C}$ for 20 hours. Figure 1 shows XRD patterns of samples prepared with and

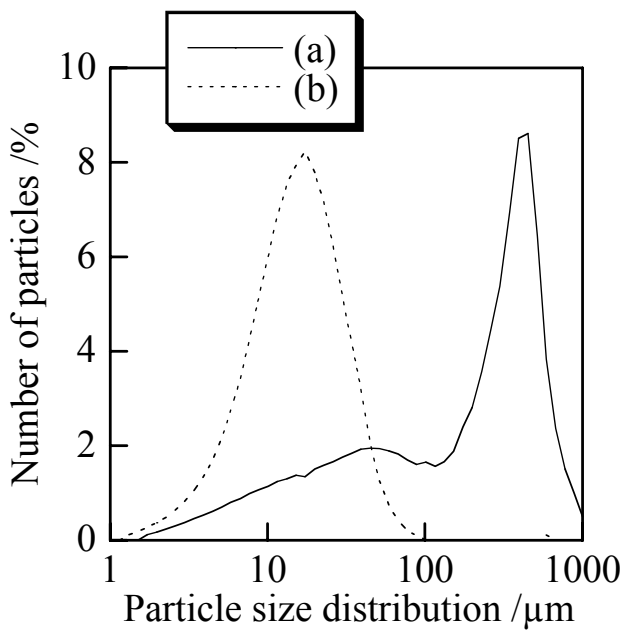

Fig. 2. Particle size distribution of $\mathrm{Ce}\left(\mathrm{PO}_{3}\right)_{4}$ treated for (a) 0 and (b) 30 min with planetary- mill. without the dopants. All samples indicated the XRD 
peaks of tetra-valent cerium polyphosphate (JCPDS Card No. 25-0188). Because the ratio of substitution was small, the peaks were not shifted and broadened by the addition of tri-valent rare earth cation.

To obtain high density of phosphate bulk, phosphate powder was milled to smaller homogenized particles. Figure 2 shows the particle size distribution of samples milled for 0 and 30 minutes. Samples without milling had high ratio of larger particle size than 100 micrometer (Fig.2 (a)). On the other hand, the particle size was from 1 to 100 micrometer in phosphate milled for 30 minutes (Fig.2 (b)).

\section{Synthesis of cerium polyphosphate bulks}

Table 1 shows the results on pressure - less sintering process. By sintering at $750{ }^{\circ} \mathrm{C}$ for 20 hours, phosphate bulk was too weak in mechanical strength to measure the electrical conductivity. Tetra-valent cerium polyphosphate was decomposed to tri-valent cerium polyphosphate, $\mathrm{Ce}\left(\mathrm{PO}_{3}\right)_{3}$, and ultraphosphate, $\mathrm{CeP}_{5} \mathrm{O}_{14}$ by heating over $800{ }^{\circ} \mathrm{C}$. The reduction of cerium cation was considered in following reactions $[4,6]$.

$$
\begin{aligned}
& 4 \mathrm{Ce}\left(\mathrm{PO}_{3}\right)_{4} \rightarrow 4 \mathrm{Ce}\left(\mathrm{PO}_{3}\right)_{3}+2 \mathrm{P}_{2} \mathrm{O}_{5}+\mathrm{O}_{2} \\
& 4 \mathrm{Ce}\left(\mathrm{PO}_{3}\right)_{4} \rightarrow 2 \mathrm{Ce}\left(\mathrm{PO}_{3}\right)_{3}+2 \mathrm{CeP}_{5} \mathrm{O}_{14}+\mathrm{O}_{2}
\end{aligned}
$$

This pressure less sintering, generally used, was not appropriate method to synthesize this phosphate bulk.

Two points were considered to decompose cerium phosphate, one was to heat for long time, and another one was at high temperature. Because spark plasma sintering (SPS) method was known to synthesize the bulk in a short time, it was tried to obtain this polyphosphate bulk. Table 2 shows the results of $\mathrm{Ce}\left(\mathrm{PO}_{3}\right)_{4}$ on SPS method. The sintering temperature was determined from linear shrinkage. The phosphate material was decomposed to the mixture of $\mathrm{Ce}\left(\mathrm{PO}_{3}\right)_{3}$ and $\mathrm{CeP}_{5} \mathrm{O}_{14}$ by sintering at $950{ }^{\circ} \mathrm{C}$ for 5 minutes. By sintering at $800{ }^{\circ} \mathrm{C}$, the phosphates were not decomposed, however the peak intensity became very weak in XRD analyses. A certain part of polyphosphate was considered to change to be amorphous phase, because the graphite mold and the decompression produced the reducing atmosphere. An example of reactions is expressed in following equation.

$4 \mathrm{Ce}\left(\mathrm{PO}_{3}\right)_{4}+\mathrm{C} \rightarrow 4 \mathrm{Ce}\left(\mathrm{PO}_{3}\right)_{3}+2 \mathrm{P}_{2} \mathrm{O}_{5}+\mathrm{CO}_{2}(5)$

This sintering process was not suitable for the measurement of electrical conductivity.

Another reason of decomposition was considered to sinter at high temperature. To synthesize the phosphate bulk at lower temperature, hydrothermal hot pressing (HHP) method was tried. Table 3 shows the experimental condition and results of $\mathrm{Ce}\left(\mathrm{PO}_{3}\right)_{4}$ on HHP method. Phosphate bulks had XRD peaks of tetra-valent cerium polyphosphate in all condition in this table. The peak intensity became a little smaller by HHP process, however it was not serious problem for the measurement of electrical conductivity. In general, large amount of solvent was required in HHP process, however the suitable solvent volume was from 0.1 to $0.3 \mathrm{ml}$ on $2 \mathrm{~g}$ of phosphate (Table 3 (a)-(c)). High temperature $\left(200{ }^{\circ} \mathrm{C}\right)$ and pressure $(80$ $\mathrm{MPa}$ ) produced the high density of phosphate bulks (Table 3 (a)(d)(e)). Ethanol was used not to decompose the polyphosphate structure in hydration reaction. However, the kind of solvent had less influence on the decomposition of polyphosphate. Water was the much effective solvent than ethanol for high relative density in this HHP process (Table 3 (a)(f)). Furthermore, the milled powder formed the bulk that had the high relative density. From above results, polyphosphate bulk for the measurement of electrical conductivity was synthesized in the condition of Table 3 (j). The $40 \mathrm{MPa}$ of pressure was settled from the apparatus problem.

Table 1 Experimental results of $\mathrm{Ce}\left(\mathrm{PO}_{3}\right)_{4}$ on Pressure Less Sintering process (heating time 20h)

\begin{tabular}{cccc}
\hline $\begin{array}{c}\text { Temperature } \\
/{ }^{\circ} \mathrm{C}\end{array}$ & $\begin{array}{c}\text { Composition } \\
\text { after sintering }\end{array}$ & $\begin{array}{c}\text { Density } \\
/ \mathrm{g} \cdot \mathrm{cm}^{-3}\end{array}$ & $\begin{array}{c}\text { Relative } \\
\text { density } / \%\end{array}$ \\
\hline 750 & $\mathrm{Ce}\left(\mathrm{PO}_{3}\right)_{4}$ & $\mathrm{X}$ & - \\
800 & $\mathrm{Ce}\left(\mathrm{PO}_{3}\right)_{4}+\mathrm{Ce}\left(\mathrm{PO}_{3}\right)_{3}$ & 2.09 & 63.9 \\
825 & $\mathrm{Ce}\left(\mathrm{PO}_{3}\right)_{4}+\mathrm{Ce}\left(\mathrm{PO}_{3}\right)_{3}+\mathrm{CeP}_{5} \mathrm{O}_{14}$ & - & - \\
\hline
\end{tabular}

$\mathrm{X}$; difficult to measure because sample is too weak.

Table 2 Experimental condition and results of cerium phosphates on Spark Plasma Sintering process

\begin{tabular}{cccccc}
\hline Temperature & Pressure & Composition & $\begin{array}{c}\text { XRD peak } \\
\text { intensity } \\
\text { after } / \text { before } \\
\text { sintering }\end{array}$ & Density & Relative \\
$/{ }^{\circ} \mathrm{C}$ & $/ \mathrm{MPa}$ & after sintering & density $/ \%$ \\
\hline 800 & 50 & $\mathrm{Ce}\left(\mathrm{PO}_{3}\right)_{4}$ & $3 / 25$ & 2.63 & 80.3 \\
950 & 50 & $\mathrm{Ce}\left(\mathrm{PO}_{3}\right)_{3}+\mathrm{CeP}_{5} \mathrm{O}_{14}$ & $10 / 25$ & 3.22 & 98.2 \\
\hline
\end{tabular}


Table 3 Experimental condition and results of $\mathrm{Ce}\left(\mathrm{PO}_{3}\right)_{4}$ on Hydrothermal Hot Pressing process

\begin{tabular}{cccccccc}
\hline & Sample & Solvent & $\begin{array}{c}\text { Solvent } \\
\text { volume } \\
/ \mathrm{ml}\end{array}$ & $\begin{array}{c}\text { Temperature } \\
/{ }^{\circ} \mathrm{C}\end{array}$ & $\begin{array}{c}\text { Pressure } \\
/ \mathrm{MPa}\end{array}$ & $\begin{array}{c}\text { Density } \\
/ \mathrm{g} \bullet \mathrm{cm}^{-3}\end{array}$ & $\begin{array}{c}\text { Relative } \\
\text { density } \\
/ \%\end{array}$ \\
\hline $\mathrm{a}$ & - & $\mathrm{C}_{2} \mathrm{H}_{5} \mathrm{OH}$ & 0.1 & 150 & 80 & 2.55 & 77.7 \\
$\mathrm{~b}$ & - & $\mathrm{C}_{2} \mathrm{H}_{5} \mathrm{OH}$ & 0.2 & 150 & 80 & 2.51 & 76.5 \\
c & - & $\mathrm{C}_{2} \mathrm{H}_{5} \mathrm{OH}$ & 0.3 & 150 & 80 & 2.58 & 78.5 \\
d & - & $\mathrm{C}_{2} \mathrm{H}_{5} \mathrm{OH}$ & 0.1 & 200 & 80 & 2.64 & 80.3 \\
e & - & $\mathrm{C}_{2} \mathrm{H}_{5} \mathrm{OH}$ & 0.1 & 150 & 40 & 2.39 & 73.2 \\
f & - & $\mathrm{H}_{2} \mathrm{O}$ & 0.1 & 150 & 80 & 2.47 & 75.2 \\
$\mathrm{~g}$ & milled & $\mathrm{C}_{2} \mathrm{H}_{5} \mathrm{OH}$ & 0.1 & 150 & 80 & 2.75 & 83.8 \\
h & milled & $\mathrm{C}_{2} \mathrm{H}_{5} \mathrm{OH}$ & 0.1 & 150 & 40 & 2.71 & 82.7 \\
i & milled & $\mathrm{C}_{2} \mathrm{H}_{5} \mathrm{OH}$ & 0.1 & 200 & 40 & 2.37 & 72.2 \\
j & milled & $\mathrm{H}_{2} \mathrm{O}$ & 0.1 & 200 & 40 & 2.74 & 83.4 \\
\hline
\end{tabular}

\section{Electrical conductivity of tetra-valent cerium polyphosphate bulks}

Figure 3 shows the electrical conductivity of various rare earth doped $\mathrm{Ce}\left(\mathrm{PO}_{3}\right)_{4}$ in $\mathrm{H}_{2} \mathrm{O}$ atmosphere. $\mathrm{Y}$ doped $\mathrm{Ce}\left(\mathrm{PO}_{3}\right)_{4}$ had higher conductivity than other materials. In previous works [1-3], the dopant, which has a little larger ionic radius than original material, much improved the conductivity of phosphate. The ionic radius is $\mathrm{Ce}>\mathrm{Gd}>\mathrm{Y}>\mathrm{Yb}$, on the other hand, the results of electrical conductivity in this work was Y-doped $>$ undoped $>\mathrm{Yb}$ nearly equal $\mathrm{Gd}$ doped material. It was difficult to clear why Y-doped $\mathrm{Ce}\left(\mathrm{PO}_{3}\right)_{4}$ had higher conductivity than $\mathrm{Gd}$ and $\mathrm{Yb}$ doped samples. It is strange that un-doped $\mathrm{Ce}\left(\mathrm{PO}_{3}\right)_{4}$ had higher conductivity than $\mathrm{Gd}$ and $\mathrm{Yb}$ doped $\mathrm{Ce}\left(\mathrm{PO}_{3}\right)_{4}$. A part of tetra-valent cerium cation was considered to reduce tri-valent cerium cation and then to work as a dopant. This effect was much depended on temperature because the slope of un-doped $\mathrm{Ce}\left(\mathrm{PO}_{3}\right)_{4}$ in Fig. 3 was large than those of other samples. In the un-doped material, the condition of cerium cation changed by heating, on the other hand, it did not change in trivalent cation doped $\mathrm{Ce}\left(\mathrm{PO}_{3}\right)_{4}$. The doped rare earth cation controlled the reduction of tetra-valent cation.

Figure 4 shows $\mathrm{H} / \mathrm{D}$ isotope effect on conductivity of various rare earth doped $\mathrm{Ce}\left(\mathrm{PO}_{3}\right)_{4}$. The tri-valent rare earth doped $\mathrm{Ce}\left(\mathrm{PO}_{3}\right)_{4}$ indicated the near square root of 2 (Fig. 2 (b)-(d)). The proton conductivity was considered to be predominant in these materials. On the other hand, un-doped $\mathrm{Ce}\left(\mathrm{PO}_{3}\right)_{4}$ had the difference behavior with other materials. The $\mathrm{H} / \mathrm{D}$ isotope value of this $\mathrm{Ce}\left(\mathrm{PO}_{3}\right)_{4}$ changed by heating (Fig. 4 (d)). This result also appealed that the condition of cerium phosphate was influenced from temperature. Because the same material was checked the re-measurement of electrical conductivity, the phosphate returned the original state from the phase at high temperature. However, it was different to clear the transition of cerium phosphate.

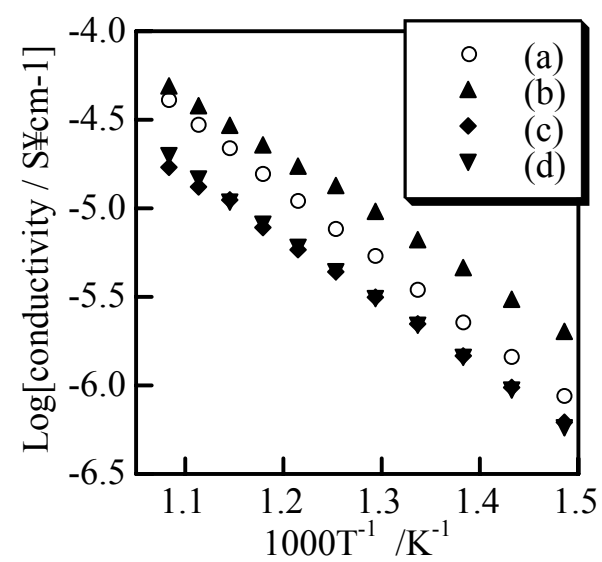

Fig. 3. Conductivity of various rare earth doped $\mathrm{Ce}\left(\mathrm{PO}_{3}\right)_{4}$, (a) un-doped, (b) $\mathrm{Y}$, (c) $\mathrm{Gd}$, and (d) Yb-doped $\left(\mathrm{H}_{2} \mathrm{O} 4.2 \mathrm{kPa}\right)$.

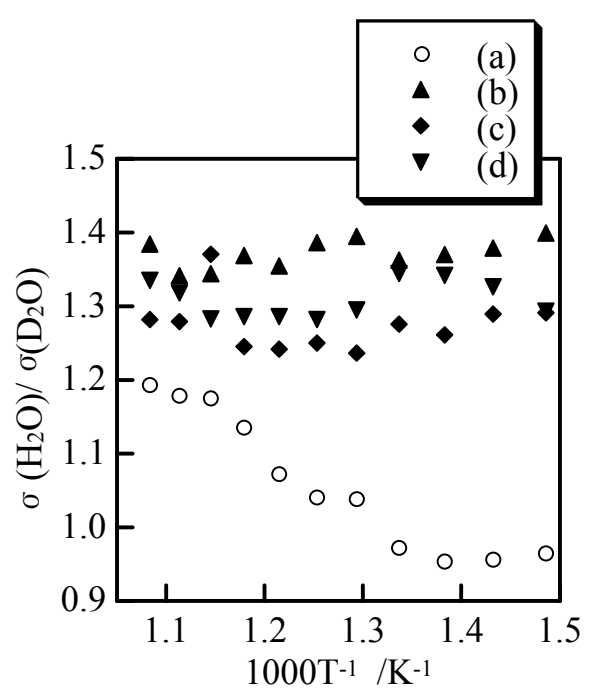

Fig. 4. H/D isotope effect on conductivity of various rare earth doped $\mathrm{Ce}\left(\mathrm{PO}_{3}\right)_{4}$, (a) un-doped, (b) Y, (c) $\mathrm{Gd}$, and (d) Yb doped. 


\section{CONCLUSION}

Tetra-valent cerium phosphate was synthesized by heating at $700^{\circ} \mathrm{C}$ for 20 hours from cerium oxide and phosphoric acid. The hydrothermal hot pressing process was the suitable method to synthesize the tetra-valent cerium phosphate bulk. $\mathrm{Y}$ doped $\mathrm{Ce}\left(\mathrm{PO}_{3}\right)_{4}$ had higher conductivity than other materials. In un-doped $\mathrm{Ce}\left(\mathrm{PO}_{3}\right)_{4}$, a part of tetra-valent cerium cation was considered to reduce tri-valent cerium cation and then work as a dopant.

\section{REFERENCES}

1. K. Amezawa, Y. Tomii, N. Yamamoto, Solid State Ionics, 176, 135 (2005).

2. K. Amezawa, Y. Tomii, N. Yamamoto, Solid State Ionics, 176, 143 (2005).

3. K. Amezawa, Y. Kitajima, Y. Tomii, N. Yamamoto, Electrochem. Solid State Lett., 7(12), A511 (2004).

4. H. Onoda, H. Nariai, A. Moriwaki, H. Maki and I. Motooka, J. Mater. Chem., 12(6), 1754
(2002).

5. H. Onoda, T. Ohta, J. Tamaki, K. Kojima, H. Nariai, Mater. Chem. Phys., 96(1), 163 (2006).

6. M. T. Averbuch, A. Durf, Topics in Phosphate Chemistry, World Scientific Publishing, Singapore, 1996.

7. C.-M. Chang, S.-H. Hong, H.-M. Park, Solid State Ionics, 176, 2583 (2005).

8. J. L. Xu, K. A. Khor, Y. W. Gu, R. Kumar, P. Cheang, Biomater., 26, 2197 (2005).

9. Y. W.Gu, N. H. Loh, K. A. Khor, S. B. Tor, P. Cheang, Biomater., 23, 37 (2002).

10. Y. Kobayashi, T. Takeuchi, M. Tabuchi, K. Ado, H. Kakegawa, J. Powder Source, 81-82, 853 (1999).

11. T. Onoki, K. Hosoi, T. Hashida, Scrip. Mater., 52, 767 (2005).

12. N. Yamasaki, K. Yanagisawa, M. Nishioka, and S. Kanahara, J. Mater. Sci. Lett., 5(3), 355 (1985).

13. M. Takimura, H. Nagata, Y. Yamasaki, T. Suzuki, Y. Ikuhara, A. Nakahira, J. Ceram. Soc. Jpn., 114(6), 554 (2006).

14. A. Nakahira, S. Takezoe, Y. Yamasaki, Chem. Lett., 33(10), 1400 (2004). 